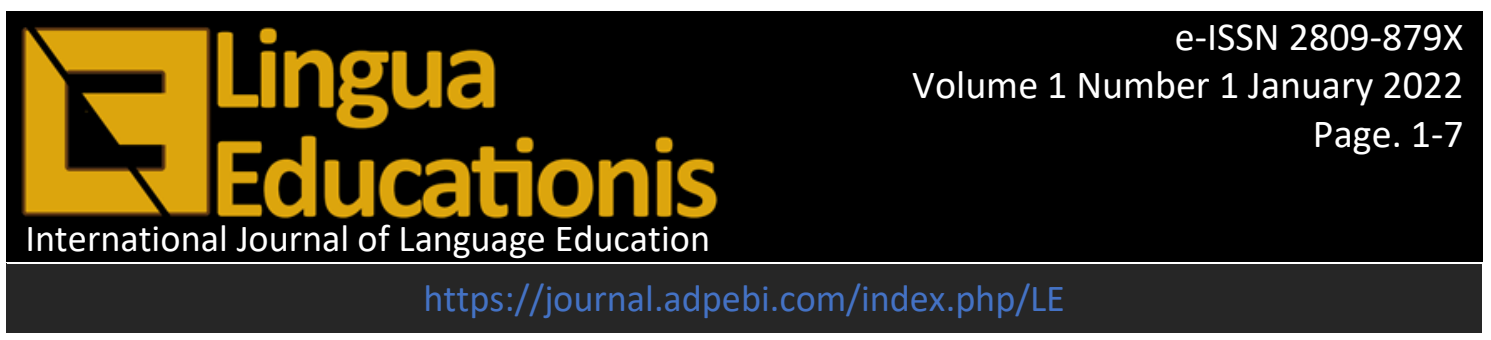

\title{
THE EFFECT OF LEARNING METHODS AND VOCABULARY MASTERY ON ENGLISH SPEAKING ABILITY
}

\author{
Lesnasari Dalimunthe ${ }^{1}$, Rofiq Noorman Haryadi ${ }^{2}$ \\ Sekolah Tinggi Ilmu Kesehatan Indonesia Maju, Jakarta, Indonesia ${ }^{1}$, \\ STEBIS Bina Mandiri, Bogor, Indonesia². \\ Emaillesnadm03@gmail.com ${ }^{1}$, rofiq.stebis@gmail.com².
}

Diserahkan: 10-12-2021 Direviu: 05-01-2022 Diterima: 15-12-2022 $\quad$ Diterbitkan: 20-01-2022

\begin{abstract}
The research title is effects of learning method and vocabulary mastery toward speaking skill (Experiments on $\mathrm{x}$ grade students of private vocational schools in Bogor). The purpose of this study is to find the influence of learning method and vocabulary mastery toward speaking skill. This research used the Experimental research methods. Inferential analysis is done by ANOVA statistics (Analysis of Variance). The results of the study conclude: (1) This is a significant effect on the learning method toward speaking skill in private vocational high school in Bogor. This can be proved by the value of sig 0,000<0,05 and count F 43,431, so it can be concluded that there is a significant difference in speaking skill in groups of students who were given Chinese Whisper learning methods. (2) There is a significant effect on vocabulary mastery toward speaking skill in private vocational school in Bogor. It can be proven by the sig value $0.002<0.05$ and count F 10.447 which means that there is a significant difference in the ability to speak in groups of students who have high and low vocabulary. (3) There is interactive a significant effect of learning method and vocabulary mastery toward speaking skill in private vocational school in Bogor. This can be proved by the sig value $0.003<0.05$ and count $\mathrm{F} 9.736$.
\end{abstract}

Keywords: Learning Method, Vocabulary Mastery, Speaking Skill

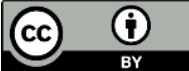

This work is licensed under a Creative Commons Attribution 4.0 International License.

\section{Introduction}

English has an important role in conveying information and communication technology ideas and for absorbing ideas from outside that can be used for the welfare of the nation and state. English is an international language that has been accepted by countries around the world. Its function is as a means of communication in fulfilling business or other activities between governments around the world as well as an introduction to communication between nations. In addition, English is used in science and technology (Science and Technology), new discoveries in the fields of modern technology, pharmacy, medical, etc., so to keep up with the development of science and technology, English mastery is required. 
There are four skills in learning English, they are listening, speaking, reading, and writing. From the four explanations above, speaking is very important because speaking and humans cannot be separated from each other. Speaking is used to express their ideas and to communicate with people all over the world. Speaking is a productive skill and cannot be separated from listening. When we tell we take out the text and it should be meaningful. In the realm of communication, we can find speakers, omniscient listeners, the Koran and feedback. Speaking cannot be separated from pronunciation as it encourages students to learn English.

Selection of learning methods that are in accordance with curriculum objectives and student potential are basic abilities and skills that must be possessed by a teacher. This is based on the assumption that the teacher's accuracy in choosing learning methods will affect the success and student learning outcomes. Approach strategies, methods and techniques that involve active students in learning, both mentally, physically, and socially. One alternative learning that can be used is learning by using a game learning model. This study uses the application of the Chinese Whisper game learning model. This teaching method is essentially exploring and developing active student involvement in the teaching and learning process and it is very good to be applied to subjects that the teacher feels are very difficult for students to understand as students often experience in English subjects.

In this game the teacher divides the class into teams and gives the last person on each team a word. When the teacher says "go", in the last stage the students whisper these words to the student in front and so on until the first one in the line has the word and walks up to the teacher and speaks. The team that speaks correctly according to the initial words then that team wins. This game is very useful for teachers to achieve instructional goals and learning objectives, as well as a tool to guide students in the teaching and learning process. Teachers should motivate students to learn English in class, so students will feel relaxed, and free to use English in class.

Considering the important role of vocabulary mastery in language learning, it must be ensured and developed properly. On the other hand, the vocabulary of teenagers will be very limited. As a result they will find difficulties in learning language skills. With a large number of students' vocabularies, students must be diligent in reading and listening. Reading will increase students' knowledge in science and information. Listening will make students understand how to pronounce the sound of a vocabulary. So that students will be able to remember the words they have read and heard.

\section{Learning Methods}

(Cahyo, 2013) The learning method is a conscious effort by the teacher to help students or students, so that they can learn according to their needs and interests. In learning, the focus is directed at how someone influences others so that the learning process occurs. According to (Sanjaya, 2019) Learning Method is a method used to implement plans that have been prepared in real activities so that the goals that have been prepared are achieved optimally. (Sukandi \& others, 2003) defines that the conventional approach is characterized by the teacher teaching more about concepts not competencies, the goal is that students know something but are not able to do something, and during the learning process students listen more. Here it can be seen that the conventional approach in question is a learning process that is dominated by the teacher as a "transfer of knowledge", while students are more passive as "recipients" of knowledge.

\section{Games In Learning}


(Shin \& Crandall, 2014) say "The games are technical to make practicing listening and speaking more fun and active", games are techniques to make practicing listening and speaking more exciting and active. (Salen et al., 2006) adds "Games are an exercise of voluntary control systems, in which there is a contest between powers, confined by rules in order to produce a disequilibrium outcome", says a game is a system in which players are involved in a conflict, artificial, defined by rules, resulting in measurable results. The game is a system that requires players to follow the rules that have been set.

\section{Learning game Chinese Whispers}

(Dale, 2004) in his book says "Where the nations of Europe and England do not understand when the community speak Chinese, they are speaking with like vague, exclusive and disorganized. (Haryadi, 2020) speaking skill is very important compared to other skills. Special skills in speaking are in the form of mastery of vocabulary, mastery of grammar, courage to start speaking, continuous speaking practice, adhering to certain guiding concepts, fluency in speech and fluency in speaking, it is necessary to have the habit of reading to acquire word for word.

Because Chinese show "confusion and do not understand' and from that moment the UK and Europe used the word "Chinese whispers" in a game of whispering or whispering game, Historians state that the beginning of contact between Europeans and Chinese in the 17th century began with the use of the Chinese language where at that time Europeans and British did not understand when the Chinese people spoke, they spoke like muttering with words that were not clear, difficult to understand and unorganized. Because the Chinese language shows "confused" and "don't understand", then from that time the British and Europeans used the word "Chinese Whispers" in a whispering game or "whispering game". Using Chinese whispering phrases, they believe that Chinese itself cannot be understood.

According to the Ministry of Education and Culture (2014: 2) that in the Chinese whispers game the teacher checks students' understanding with the questions, "To whom will I show the sentence?", "What will the students in the front do?", "What will the students in the back do?" do?", "Who will be the winner?"

\section{Definition of Vocabulary Mastery}

(Hiebert \& Kamil, 2005) explain "Vocabulary mastery is the ability to express the meaning of words, patterns with information, meanwhile passive vocabulary means the ability of recognizing the form and the meaning of words", that vocabulary mastery is the ability to express the meaning of words. -words, the formation of patterns of words. The vocabulary in question is the meaning of words. This definition is a fact that vocabulary can be said to be very active and passive. Active vocabulary is vocabulary whose frequency of use is very often used in speaking. (Haryadi et al., 2021) vocabulary gives an important part for language learning in foreign language.

\section{The Essence of the Ability to Speak}

(Brown \& Abeywickrama, 2010) reveals that speaking is a productive skill that can be directly and empirically observed, an observation that is always colored by the accuracy and effectiveness of test-taker skills, as the quote says, "While speaking is a productive skill that can be directly and empirically observed, those observations are invariably colored by the accuracy and effectiveness of a test-takers listening skill". (Thornbury, 2005) said that speaking is speech production that becomes part of our daily activities. Most speaking activities are in the form of face-to-face dialogue, so speaking involves relationships. Speaking is a person's ability to communicate orally to be able to 
converse and explain the intent when face to face with other people. "Talk is a person capacity to communicate verbally to be able to speak and explain when face to face with others".

\section{Research Methods}

The study used experimental techniques, namely by giving different types of treatment to the two student study groups. One group was used as the experimental group, which was given treatment (treatment) learning techniques with game techniques, while the other group as a control group with treatment (treatment) using conventional techniques. From each of these groups, then they are divided into 2 (two) categories of student groups based on the level of vocabulary mastery they have, namely groups of students with high vocabulary mastery and groups of students with low vocabulary mastery.

The population in this study were students of class X SMK Teknomedika Plus totaling 235 students and SMK Bina Mandiri Multimedia totaling 230 students, so the total research population was 465 students. The sample to be determined in this study is $10-15 \%$ of the population. It is known that the students of SMK Teknomedika Plus and SMK Bina Mandiri Multimedia Bogor with a total of 465 students. So $10-15 \%$ is taken, meaning that the sample is between 46-70 students. The average number of students in class X at SMK Teknomedika Plus and SMK Bina Mandiri Multimedia is 30 students, but the sample taken is 60 students (two study classes, each class 30 students).

The two classes consisted of 60 students, each class consisting of 30 students from the experimental group and 30 students from the control group. After the test, the score obtained from the test, then ranked as much as 33\% of the upper group and declared as high vocabulary mastery students while $33 \%$ of the lower group stated as low vocabulary mastery. The determination of high vocabulary mastery and low vocabulary mastery was $33 \%$.

Table 1

Determination of the Treatment of Each Group Each Class

\begin{tabular}{ccc}
\hline Action/Treatment & Game Techniques & Conventional Techniques \\
\hline High Vocabulary Mastery & 15 & 15 \\
Low Vocabulary Mastery & 15 & 15 \\
Total & $\mathbf{3 0}$ & $\mathbf{3 0}$ \\
\hline
\end{tabular}

The data collection technique in this study was for students' English speaking ability (Y), namely the results of the test instrument questions for students in class $\mathrm{X}$, experimental class and control class. The score obtained from the English speaking ability test is the score obtained by each student in doing a speaking ability test by giving an evaluation through a verbal speaking test to class $\mathrm{X}$ students as the research sample. The research instrument describes the research data collection tools used by researchers in conducting the research data collection process. The instrument used to obtain vocabulary mastery data is a multiple-choice test with 25 questions. Each respondent who answered correctly one item was given a score of 4 and those who answered incorrectly were given a score of 0 . Thus, the lowest score was 4 and the highest was 100 . While the instrument used to obtain speech data was an oral test asking students to provide information about the identity of the relationship. The family uses the appropriate language (pronoun, subjective, objective, possessive) elements according to the context of the user. The 
maximum score is 4 and the minimum score is 1 , theoretically the lowest score is 25 students and the highest score is 100 .

Data Analysis Techniques by analyzing descriptive statistics, namely the Data Analysis Requirements Test was carried out using the Normality Test and Homogeneity Test. After that, doing Research Hypothesis Testing, In the research conducted by the author aims to test the difference in the average score with 2 independent variables, then the research hypothesis testing used is a two-way analysis of variance (ANOVA) $2 \times 2$.

Table 2

2x2. Factorial Bidirectional ANOVA Design

\begin{tabular}{cccc}
\hline Learning Methods/Vocabulary Mastery & A-1 & A-2 & A-3 \\
\hline B-1 & Y11 & Y12 & Y10 \\
B-2 & Y12 & Y22 & Y20 \\
$\sum K$ & Y01 & Y02 & Y00 \\
\hline
\end{tabular}

\section{Result}

The results of the research test concluded, namely 1 . There was a significant effect of learning methods on English speaking skills of Class X private vocational high school students in Bogor. This can be proven by the value of sig $0.000<0.05$ count $F$ 43,431, it is concluded that there is a significant difference in speaking ability in the group of students who were given the Chinese Whisper learning method. 2. There is a significant effect of vocabulary mastery on the English speaking ability of Class X private vocational high school students in Bogor. This can be proven by the value of sig $0.002<0.05$ and count F10.447 which means that there is a significant difference in speaking ability in the group of students who have high and low vocabulary. 3 . There is a significant interactive effect of learning methods and vocabulary mastery on the English speaking ability of students in Class X private vocational schools in Bogor. This can be proven by the value of sig $0.003<0.05$ and count F 9.736, so the conclusion is that there is a significant interactive effect of learning methods (Chinese whisper and Conventional) and vocabulary mastery (high and low) on the ability to speak English of class X private vocational high school students in Bogor.

Table 3

Hypothesis test

Tests of Between-Subjects Effects

\begin{tabular}{lrrrrr}
\hline Source & Type III Sum of Squares & df & Mean Square & \multicolumn{1}{c}{ F } & Sig. \\
\hline Corrected Model & $5415,517^{\text {a }}$ & 3 & $1,805,172$ & 21,205 &, 000 \\
Intercept & $265,734,150$ & 1 & $265,734,150$ & $3,121,475$ &, 000 \\
A & $3,697,350$ & 1 & $3,697,350$ & 43,431 &, 000 \\
B & 889,350 & 1 & 889,350 & 10,447 &, 002 \\
A * B & 828,817 & 1 & 828,817 & 9,736 &, 003 \\
Error & $4,767,333$ & 56 & 85,131 & & \\
Total & $275,917,000$ & 60 & & & \\
Corrected Total & $10,182,850$ & 59 & & & \\
\hline
\end{tabular}

a. R Squared $=, 532($ Adjusted R Squared $=, 507)$ 


\section{Conclusion}

The effect of the learning method on the ability to speak English. The results of the study for the category of giving the Chinese whisper game learning method to the group of students with high vocabulary mastery had an average value of speaking ability that was higher than the average value of speaking ability in the group of students with low vocabulary mastery. Likewise with the provision of conventional methods, the provision of conventional learning methods with high vocabulary mastery has a higher average value of speaking ability than the group of students with low vocabulary mastery. Based on the results of hypothesis testing, it can be analyzed that there is an influence of learning methods on the English speaking skills of class X private vocational high school students in Bogor, both using the Chinese whisper game learning method and using conventional methods. The test results concluded that there was a significant effect on giving the Chinese whisper game learning method to the speaking ability of the students of class X private vocational schools in Bogor.

The effect of vocabulary mastery on English speaking ability. The test results for the vocabulary mastery category have a sig value of $0.000(<0.05)$, which means that there is a significant difference in speaking ability with high and low vocabulary mastery. It is very clear that vocabulary mastery has a very important role. in improving students' English speaking skills. Someone with high vocabulary mastery will have high English speaking ability when compared to students who have low vocabulary mastery. The test results concluded that there was a significant effect of vocabulary mastery on the English speaking ability of class $\mathrm{X}$ private vocational high school students in Bogor.

Interactive effect of learning methods and vocabulary mastery on English speaking ability. From the test table of Between-Subject Effects, it is also known that the p-value for the interaction of learning methods and vocabulary mastery is $0.003(<0.05)$ which means that there is a significant difference between the interactive Chinese whisper and conventional learning methods with vocabulary mastery (high and low). ). The results showed that giving the Chinese whisper game learning method to the group of students with high vocabulary mastery had the highest average value of speaking ability compared to the other three groups. For the category of giving conventional learning methods with high vocabulary mastery, the average value of speaking ability is higher than the group of students with low vocabulary mastery.

\section{References}

Brown, H. D., \& Abeywickrama, P. (2010). Language assessment: Principles and classroom practices (Vol. 10). Pearson Education White Plains, NY.

Cahyo, A. N. (2013). Panduan aplikasi teori-teori belajar mengajar teraktual dan terpopuler. DIVA Pers: Yogyakarta.

Dale, C. H. (2004). Chinese aesthetics and literature: A reader. SUNY Press.

Haryadi, R. N. (2020). Pengaruh PENGARUH KEBIASAAN MEMBACA TERHADAP KEMAMPUAN BERBICARA BAHASA INGGRIS SMA Negeri 99 Jakarta. Jurnal Manajemen Bisnis Dan Keuangan, 1(2), 14-30.

Haryadi, R. N., Endah, J., \& Dalimunthe, L. (2021). THE EFFECTS OF VOCABULARY AND GRAMMAR MASTERY ON STUDENTSWRITING SKILL IN DESCRIPTIVE TEXT (Surveys at Private Junior High Schools in Serang Banten). JLE: Journal of Literate of English Education Study Program, 2(2), 46-54.

Hiebert, E. H., \& Kamil, M. L. (2005). Teaching and learning vocabulary: Bringing research to practice. Routledge. 
The Effect of Learning Methods and Vocabulary Mastery on English Speaking Ability. Lesnasari Dalimunthe, Rofiq Noorman Haryadi

Salen, K., Tekinbas, K. S., \& Zimmerman, E. (2006). The game design reader: A rules of play anthology. MIT press.

Sanjaya, W. (2019). Strategi pembelajaran berorientasi standar proses pendidikan.

Shin, J. K., \& Crandall, J. (Jodi). (2014). Teaching young learners English: From theory to practice. National Geographic Learning.

Sukandi, U., \& others. (2003). Belajar aktif dan terpadu. Surabaya: Duta Graha Pustaka. Thornbury, S. (2005). How to teach speaking. Longman. 